\title{
Composted Municipal Waste Reduces Infection of Citrus Seedlings by Phytophthora nicotianae
}

T. L. Widmer, Former Graduate Assistant, Department of Plant Pathology, University of Florida, IFAS, Gainesville 32611; J. H. Graham, Professor, Citrus Research and Education Center, University of Florida, Institute of Food and Agricultural Sciences, 700 Experiment Station Road, Lake Alfred 33850; and D. J. Mitchell, Professor, Department of Plant Pathology, University of Florida, IFAS, Gainesville 32611

\section{ABSTRACT}

Widmer, T. L., Graham, J. H., and Mitchell, D. J. 1998. Composted municipal waste reduces infection of citrus seedlings by Phytophthora nicotianae. Plant Dis. 82:683-688.

\begin{abstract}
Most citrus nurseries and orchards in Florida are infested with Phytophthora nicotianae, the causal agent of Phytophthora root rot. Although fungicides control the disease and increase seedling growth and tree yields, they are not always economically or environmentally sustainable. Amendment of citrus soils with composted municipal waste (CMW) may provide an alternative to fungicides for disease management. Citrus seedling growth decreased with increasing proportions of one CMW source, indicating the potential for phytotoxicity from soluble salts and acetic acid when the proportion of CMW in soil exceeded $20 \%$ (vol/ $/ \mathrm{vol}$ ). When a citrus soil was amended $(20 \% \mathrm{vol} / \mathrm{vol})$ with certain sources of CMW, the incidence of infection of 5-weekold susceptible citrus seedlings by $P$. nicotianae was reduced from $95 \%$ to as low as $5 \%$. Addition of fresh CMW to two different citrus soils reduced colony growth of $P$. nicotianae after the fungus was incubated in the amended soil for 6 days and then recovered on PARPH selective medium. If CMW was stored for more than 3 months before amendment, the soil mixtures did not suppress colony development. In general, extracts of fresh CMW reduced mycelial growth in vitro; whereas suppressiveness of CMW from the same batch was lost after storage. Acetic acid was detected at higher concentration in fresh CMW that suppressed colony growth than in CMW that lacked activity. A species of Acremonium was isolated from another source of CMW that was suppressive to P. nicotianae. This fungus parasitized hyphae of $P$. nicotianae in vitro. Thus, CMWs have the potential to at least temporarily suppress $P$. nicotianae through chemical and microbial agents depending on source and age of the CMW.
\end{abstract}

Phytophthora nicotianae Breda de Haan (synonym $=P$. parasitica Dastur) causes a rot of fibrous citrus roots in citrus nurseries and orchards in Florida (14,41). In 1993, over $90 \%$ of the nurseries surveyed in Florida were infested with $P$. nicotianae $(11,33)$. Commonly used rootstocks, such as sour orange (Citrus aurantium L.), Carrizo citrange $(C$. sinensis (L.) Osbeck $\times$ Poncirus trifoliata (L.) Raf.), and Swingle citrumelo $(C$. paradisi Macf. $\times P$. trifoliata), range from susceptible to tolerant of Phytophthora root rot $(1,13)$. However, because of citrus blight, viral diseases, other pest problems, and horticultural traits, the use of rootstocks tolerant to Phytophthora root rot may not always be feasible (14). In infested nurseries, even tolerant rootstocks suffer serious root rot damage when overwatered $(4,16)$. Resistance to metalaxyl developed in several

Corresponding author: J. H. Graham

E-mail: jhg@icon.lal.ufl.edu

Florida Agricultural Experiment Station Journal Series no. R-06216.

Accepted for publication 12 March 1998.

Publication no. D-1998-0413-03R

(C) 1998 The American Phytopathological Society
Florida citrus nurseries when the fungicide was routinely applied to control $P$. nicotianae (33). Because of continual disease pressure in nurseries and orchards, and concern with the environmental fate in soil and cost of repeated fungicide applications, new strategies for management of Phytophthora root rot of citrus are being sought.

Soil amendments such as composted organic matter are often beneficial to plant health. Incorporation of mature composts increases yields and plant and fruit size $(3,15,28)$. Composts can also suppress plant diseases caused by soilborne organisms $(2,7,17,21,29,31)$. This suppression has been demonstrated mainly with composted tree bark; whereas the use of composted municipal waste (CMW) to suppress plant diseases has received less attention $(22,31)$.

Currently, there are no regulations regarding compost production and quality. For agricultural uses, compost should be stable with a favorable $\mathrm{C}: \mathrm{N}$ ratio to facilitate slow mineralization of $\mathrm{N}$ and other nutrients after the composting process is complete (24). If compost is immature, the product is difficult to handle, may have an offensive odor, and may contain salts and metabolites toxic to plants (43). As an example, plant growth was inhibited when immature CMW was incorporated into a tomato field 1 month before planting at a rate of $75 \mathrm{MT} / \mathrm{ha}$ (28). Certain tests have been developed to determine compost maturity $(12,42)$. Guidelines for compost quality in Florida have been suggested; however, compost manufacturers are not required to adhere to these guidelines (9). Various tests, including seedling bioassays and chemical assays, and correlation studies of microbial changes have been used to study the potential for a compost to suppress plant pathogens $(6,18,25)$.

The objective of this study was to evaluate CMWs of different sources and ages for effectiveness in suppression of Phytophthora root rot of citrus in Florida soils. Suppressive CMWs and their extracts were studied further to identify potential chemical and microbial agents involved in disease suppression and their effects on $P$. nicotianae with in vitro bioassays.

\section{MATERIALS AND METHODS \\ Media and inoculum production.} Strain P-1 of $P$. nicotianae, isolated from citrus roots, was maintained on clarified V8 juice agar. Chlamydospores of $P$. nicotianae were produced by the method of Mitchell and Kannwischer-Mitchell (27).

Candler fine sand (uncoated, hyperthermic Typic Quartzipsamments) collected near Davenport, Florida, was steam-treated for $5 \mathrm{~h}$ at $120^{\circ} \mathrm{C}$ at $0.1 \mathrm{MPa}$ matric pressure. Soil was infested with $P$. nicotianae by mixing chlamydospores of the pathogen into the steamed soil and storing the infested soil for 1 week in the dark at room temperature. Density of $P$. nicotianae chlamydospores per $\mathrm{cm}^{3}$ of soil in the inoculant was determined by diluting $1 \mathrm{~g}$ of the infested soil in $40 \mathrm{ml}$ of $0.25 \%$ water agar and placing 1-ml aliquots of the suspension on the selective agar medium PARPH (pimaricin-ampicillin-rifampicinpentachloronitrobenzene-hymexazol) (27) .

Compost sources. Four batches of fresh CMW were used in the experiments: two batches from Reuter Recycling, Inc., Pembroke Pines, FL (R1 and R3), and two from Bedminster Bioconversion, Inc., Sevierville, TN (B2 and B4). Reuter CMW was composed of household garbage with recyclable and hazardous material removed. Batch R1 was divided into two sub-batches, one designated R1a, which was stored at $4^{\circ} \mathrm{C}$, and the other designated 
R1b, which was stored at room temperature. Bedminster CMW was a co-composted mixture of municipal solid waste (90\%) and wastewater residuals (10\%). Each CMW was analyzed for total C, N, P, $\mathrm{K}, \mathrm{Ca}, \mathrm{Mg}, \mathrm{Cu}, \mathrm{Mn}, \mathrm{Zn}, \mathrm{Fe}, \mathrm{Pb}, \mathrm{Cd}$, and $\mathrm{Ni}$ concentrations by the soil testing laboratory at the University of Florida, Gainesville. Bulk density of each CMW was determined by weighing $100 \mathrm{~cm}^{3}$ of air-dried material.

The $\mathrm{pH}$ of CMW and CMW-amended soil was measured by the method of Peech (30). Ten $\mathrm{g}$ of soil or medium was mixed with $20 \mathrm{ml}$ of $0.01 \mathrm{M} \mathrm{CaCl}_{2}$ solution, stirred several times over $30 \mathrm{~min}$, and allowed to stand for another $30 \mathrm{~min}$ before $\mathrm{pH}$ measurement. Electrical conductivity of CMW and CMW-amended soil was determined by a modified procedure of Warnke (36). Four hundred $\mathrm{cm}^{3}$ of the soil or medium was saturated with deionized water to a consistency at which the mixture flowed, but no appreciable water accumulated on the surface. After incubation for 1 $\mathrm{h}$, the sample was stirred again, incubated for $30 \mathrm{~min} \mathrm{more,} \mathrm{and} \mathrm{filtered} \mathrm{through}$ Whatman no. 41 filter paper (Whatman Limited, Maidstone, England). The filtrate was centrifuged for $30 \mathrm{~min}$ at 2,500 $\times \mathrm{g}$. Electrical conductivity $(\mathrm{mS} / \mathrm{cm})$ of the supernatant was measured with an ElectroMark Analyzer conductivity meter (Markson Scientific Co., Mara, CA).

Effect of CMW on seedling growth. Candler fine sand was pasteurized by microwaving $1 \mathrm{~kg}$ of moist soil (approximately 7\% wt/wt moisture) for 4 min in an 800-W microwave oven $(10,39)$. Composted municipal waste batch B4 was mixed with the pasteurized soil to final concentrations of 10, 20, and $50 \%$ (vol/vol). Sour orange (Citrus aurantium L.) seedlings were grown from seed in
Metro-Mix 500 (The Scotts Co., Marysville, $\mathrm{OH}$ ) for 5 weeks and were planted individually in $250-\mathrm{cm}^{3}$ Cone-tainers (Stuewe \& Sons, Inc., Corvallis, OR) containing either nonamended soil or CMWamended soil (10 replicates per treatment). Seedlings were set up in the greenhouse in a completely randomized design for 8 weeks, fertilized once a week with Peter's 20-10-20 fertilizer (United Industries Corp., St. Louis, MO), and watered as necessary. At harvest, seedling roots were carefully washed to remove any soil. Fresh weight of the shoots and roots of each seedling was measured, and roots were dried at $70^{\circ} \mathrm{C}$ for 3 days and weighed. The experiment was repeated once with similar results.

Infection of citrus seedlings by $P$. nicotianae. Five-week-old seedlings of Ridge Pineapple sweet orange $(C$. sinensis), citrumelo hybrids F80-3 and F80-8 (Poncirus trifoliata $\times C$. paradisi), Cleopatra mandarin (C. reshni Hort. ex Tan.), Volkamer lemon (C. volkameriana Ten. \& Pasq.), and sour orange were grown from seed in Metro-Mix 500.

Batches R1a, R1b, R3, B2, and B4 of CMW were mixed with pasteurized soil to a final volume of $20 \%$ ( vol/vol). Batch B4 was also mixed to a final CMW volume of $10 \%$ (vol/vol). Chlamydospore-infested stock soil was added to inoculated treatments for a final population density of 10 chlamydospores per $\mathrm{cm}^{3}$ of soil. Seedlings (10 replicates per treatment) were transplanted into $75-\mathrm{cm}^{3}$ Cone-tainers filled with soil that was either infested with $P$. nicotianae or noninfested, and amended with CMW or nonamended. The plants were set up in a completely randomized design in a greenhouse. Seedlings were watered on a regular schedule and fertilized weekly with Peter's 20-10-20 fertil-

Table 1. Analysis of composted municipal wastes $(\mathrm{CMW})^{\mathrm{x}}$

\begin{tabular}{lccccc}
\hline & \multicolumn{2}{c}{ Reuter $^{\mathbf{y}}$} & & \multicolumn{2}{c}{ Bedminster $^{\mathbf{y}}$} \\
\cline { 2 - 3 } \cline { 5 - 6 } Element & $\mathbf{R 1}$ & $\mathbf{R 3}$ & & $\mathbf{B 2}$ & $\mathbf{B}$ \\
\hline $\mathrm{g} \mathrm{kg}^{-1}$ & & & & 33 & \\
$\mathrm{C}$ & 347 & 240 & & 334 & $\mathrm{ND}^{\mathbf{z}}$ \\
$\mathrm{N}$ & 8.5 & 10.7 & & 17.1 & $\mathrm{ND}$ \\
$\mathrm{P}$ & 1.3 & 2.5 & & 2.6 & 2.9 \\
$\mathrm{Ca}$ & 25.4 & 52.5 & & 33.8 & 24.8 \\
$\mathrm{Mg}$ & 1.5 & 2.1 & & 2.3 & 2.4 \\
$\mathrm{~K}$ & 2.5 & 2.3 & & 3.2 & 3.4 \\
$\mathrm{Na}$ & 3.8 & 3.6 & & $\mathrm{ND}$ & $\mathrm{ND}$ \\
$\mathrm{mg} \mathrm{kg}{ }^{-1}$ & & & & \\
$\mathrm{Zn}$ & 384 & 779 & & 563 & 423 \\
$\mathrm{Cu}$ & 123 & 323 & & 175 & 165 \\
$\mathrm{Mn}$ & 158 & 248 & & 260 & 210 \\
$\mathrm{Fe}$ & 3,240 & 7,610 & & 13,425 & 8,805 \\
$\mathrm{Cd}$ & 5 & 5 & & 4 & 2 \\
$\mathrm{~Pb}$ & 272 & 406 & & 250 & 212 \\
$\mathrm{Ni}$ & 18 & 42 & & 35 & 34 \\
$\mathrm{C}: \mathrm{N}$ ratio & $40.9: 1$ & $22.4: 1$ & & $19.9: 1$ & $\mathrm{ND}$ \\
$\mathrm{pH}$ & 7.66 & 7.50 & 7.91 & 7.52 \\
\hline
\end{tabular}

${ }^{x}$ CMWs were analyzed within 6 months after composting.

${ }^{y}$ CMW from Reuter Recycling in Pembroke Pines, FL (Reuter) and Bedminster Bioconversion in Sevierville, TN (Bedminster).

${ }^{\mathrm{z}}$ Not determined. izer. After 3 weeks, the plants were removed and the roots were rinsed with tap water. Shoots were removed, and the roots were surface-sterilized in $70 \%$ ethanol for $5 \mathrm{~s}$ and rinsed twice with sterile, deionized water. The roots were placed on a sterile paper towel and flattened with a glass bottle. Each root system was placed on an individual petri plate containing PARPH medium. Plates were incubated for 2 days at $27^{\circ} \mathrm{C}$. Roots were rated positive for incidence of infection if any colonies of $P$. nicotianae were detected. The experiment was performed two times for each treatment, and data were combined, unless otherwise noted.

Effect of CMW on colony growth. One $\mathrm{kg}$ samples of Candler fine sand and Wabasso fine sand (siliceous, hyperthermic Alfic Haplaquod), collected near Fort Pierce, Florida, were pasteurized by microwaving for $4 \mathrm{~min}$. Fresh batches R1a, $\mathrm{R} 1 \mathrm{~b}, \mathrm{R} 3$, and B2 of CMW were mixed with the soils to a final proportion of $20 \%$ (vol/vol). Batch B4 was mixed with Candler fine sand to final proportions of 10 and $20 \%$ ( $\mathrm{vol} / \mathrm{vol}$ ).

Infested soil media were prepared by adding chlamydospore-infested stock soil to a final density of 10 chlamydospores per $\mathrm{cm}^{3}$ in either nonamended soil or CMWamended soil. The infested soils were mixed and maintained at room temperature in closed, but unsealed, plastic bags for 6 days. Forty g of infested CMW-amended soil or nonamended soil was mixed with 40 $\mathrm{ml}$ of $0.25 \%$ water agar. One $\mathrm{ml}$ was plated onto the PARPH selective medium (10 replicates per treatment), and the plates were incubated at $27^{\circ} \mathrm{C}$ for 2 days. The soil was washed off the plates, and the plates were placed back into the incubator. Colony areas of $P$. nicotianae on the plates were marked after $66 \mathrm{~h}$.

Colony area was estimated by overlaying the marked colonies on a $1-\mathrm{cm}$ grid. The area of the colony was calculated by adding the number of grid points within the marked colony and dividing by four to calculate the colony area in $\mathrm{cm}^{2}$. The experiment was repeated one time for each CMW treatment.

Effect of sterile CMW extracts on colony growth. One hundred $\mathrm{g}$ of Candler fine sand, $20 \mathrm{~g}$ of fresh batch B2, or $20 \mathrm{~g}$ of fresh batch R1a was mixed with $100 \mathrm{ml}$ of either $0.4 \mathrm{~N} \mathrm{KOH}, 2 \mathrm{~N} \mathrm{H}_{2} \mathrm{SO}_{4}$, or sterile, cold, double-distilled water in 250-ml flasks for $6 \mathrm{~h}$. Each suspension was filtered through cheesecloth and Whatman no. 50 filter paper. The filtrate was sterilized by filtration through a $0.2-\mu \mathrm{m}$ membrane (Gelman Sciences, Ann Arbor, MI).

One hundred $\mathrm{ml}$ of each sterile filtrate was added to individual flasks of $900 \mathrm{ml}$ of liquid Difco (Detroit, MI) cornmeal agar (CMA) supplemented with $1 \mathrm{ml}$ of tergitol NP-10 (Sigma Chemical Co., St. Louis, MO), $100 \mathrm{mg}$ of streptomycin sulfate (Sigma), and $50 \mathrm{mg}$ of chlortetra- 
cycline (Sigma). The $\mathrm{pH}$ was adjusted to 5.5 to 6.0 with either $10 \mathrm{~N} \mathrm{KOH}$ or $12 \mathrm{M}$ $\mathrm{H}_{2} \mathrm{SO}_{4}$. Fifteen $\mathrm{ml}$ of the cooled $\left(50^{\circ} \mathrm{C}\right)$ medium was poured into each of 10 petri plates. A 5-mm disk from a 5-day-old culture of $P$. nicotianae grown on $\mathrm{V} 8$ juice agar was placed in the middle of each plate, and the plates were incubated at $27^{\circ} \mathrm{C}$. The colony diameters were measured after $88 \mathrm{~h}$. The experiment was repeated once.

Isolation of microbial antagonists. Fresh batches R1a, R3, and B2 of CMW were each diluted by adding $0.33 \mathrm{~g}$ (dry weight) of the CMW to 1 liter of sterile deionized water amended with $0.5 \mathrm{ml}$ of tergitol NP-10, $100 \mathrm{mg}$ of streptomycin sulfate, and $50 \mathrm{mg}$ of chlortetracycline. One $\mathrm{ml}$ of suspension was pipetted into each of 10 sterile petri plates $(100 \times 15$ $\mathrm{mm}$ ) and mixed with $16 \mathrm{ml}$ of cooled $\left(50^{\circ} \mathrm{C}\right)$ potato dextrose agar (PDA) amended with $100 \mathrm{mg}$ of streptomycin sulfate, $50 \mathrm{mg}$ of chlortetracycline- $\mathrm{HCl}$, and $0.5 \mathrm{ml}$ of tergitol NP-10 per liter of medium. The plates were incubated under continuous light at room temperature until colonies appeared. Individual colonies were transferred aseptically to PDA amended with $100 \mathrm{mg}$ of streptomycin sulfate and $50 \mathrm{mg}$ of chlortetracycline- $\mathrm{HCl}$ per liter of medium. Fifty individual colony types of fungi were transferred as a plug to CMA plates at the opposite edge from a 2-day-old colony of $P$. nicotianae. Plates were incubated at $25^{\circ} \mathrm{C}$ and observed periodically for interactions between fungal colonies and $P$. nicotianae.

For isolation of bacteria from CMW, batches R1a, R3, and B2 were diluted by adding $0.33 \mathrm{~g}$ (dry weight) of the CMW to 1 liter of sterile distilled water amended

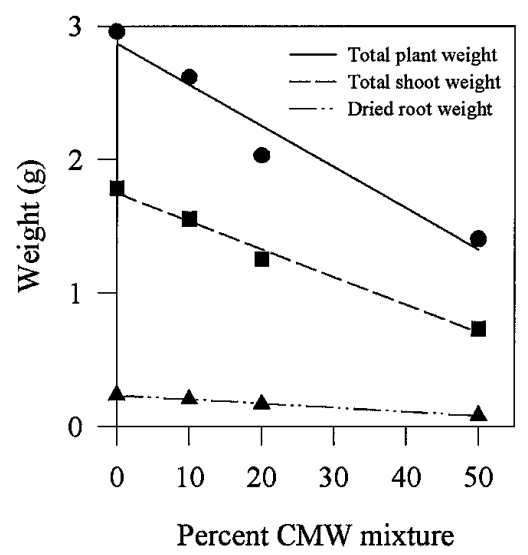

Fig. 1. Effect of amendment of Candler fine sand with batch B4 of composted municipal waste (CMW) on the total plant fresh weight $(\bullet)$, fresh shoot weight (घ), and dried root weight $(\mathbf{\Lambda})$ of sour orange seedlings grown for 8 weeks. The regression lines fit the following equations: $y=2.9-0.04 x\left(r^{2}=0.98\right)$ for total plant weight, $y=1.7-0.02 x\left(r^{2}=0.96\right)$ for total shoot weight, and $y=0.26-0.004 x\left(r^{2}=0.94\right)$ for dried root weight. with $100 \mathrm{mg}$ of cycloheximide (Sigma). Ten $\mathrm{ml}$ of the mixture of each CMW was added to $990 \mathrm{ml}$ of sterile water amended with $100 \mathrm{mg}$ of cycloheximide. One $\mathrm{ml}$ of suspension pipetted into each of 10 sterile petri plates and mixed with $16 \mathrm{ml}$ of cooled $\left(50^{\circ} \mathrm{C}\right)$, dilute Difco Tryptic Soy Broth (TSB) (3.0 g of TSB and $15 \mathrm{~g}$ of agar in 1 liter of water) amended with 100 $\mathrm{mg}$ of cycloheximide. The plates were incubated in the dark at $25^{\circ} \mathrm{C}$. Individual colonies of bacteria observed growing on the medium were transferred aseptically to petri plates of TSB amended with $100 \mathrm{mg}$ of cycloheximide per liter. More than 100 individual colonies of bacterial isolates were streaked on the edge of CMA plates, incubated for 3 days, and seeded in the middle of the plate with a 5-mm disk of $P$. nicotianae. The plates were incubated at $25^{\circ} \mathrm{C}$ and were observed periodically for interactions between the bacteria and $P$. nicotianae.

Chromatography. One g of fresh batch $\mathrm{R} 1, \mathrm{R} 3$, or B2 of CMW and $4 \mathrm{~g}$ of Candler fine sand were placed in 150-ml Erlenmeyer flasks. Ten $\mathrm{ml}$ of optima grade methanol (Sigma) was added to the mixture and stirred with a magnetic stir bar for $15 \mathrm{~min}$. The extract was filtered through a fritted glass filter by vacuum. The filtrate was stored in a sealed glass vial.

Either 2.0 or $0.5 \mu \mathrm{l}$ of the filtrate sample was injected into a Hewlett Packard 5890A gas chromatograph equipped with a $30-\mathrm{m} \times$ $0.32-\mathrm{mm}$ column coated with a $1.0-\mu \mathrm{m}$ film of Stabilwax (carbowax) (Restek Corporation, Bellefonte, PA). The carrier gas, helium, was set at a flow rate of $2 \mathrm{ml} / \mathrm{min}$. Initial temperature of the column, $40^{\circ} \mathrm{C}$, was maintained for $3 \mathrm{~min}$, and temperature was then increased at a rate of $8^{\circ} \mathrm{C}$ per min to a final temperature of $200^{\circ} \mathrm{C}$. The total run time was $23 \mathrm{~min}$. Standards of acetic acid, methanol, and isopropanol were tested.

Batch B4 was also tested using a modified headspace, solid-phase microextraction technique $(32,40)$. Fifteen $\mathrm{cm}^{3}$ of fresh batch B4 of CMW was placed in a 50-ml glass vial with a Teflon septum lid. The sample was incubated at room temperature for $24 \mathrm{~h}$. A needle was pierced through the septum of the vial, and a plunger was depressed to introduce a 1-cm-long, 100- $\mu$ mthick, poly(dimethylsiloxane)-coated fiber (Supelco, Inc., Bellefonte, PA) into the headspace of the vial for $30 \mathrm{~min}$. The fiber was withdrawn into the needle and transferred to the injection port of the gas chromatograph (GC). The needle penetrated the septum of the GC inlet, and the fiber was exposed in the $200^{\circ} \mathrm{C}$ injection port of a Hewlett Packard 5890A gas chromatograph. Compounds were separated using a $30-\mathrm{m} \times 0.32-\mathrm{mm}$ column with a $0.5-\mu \mathrm{m}$ film of DB5 (Resteck). Helium, the carrier gas, was set at a flow rate of $2 \mathrm{ml} / \mathrm{min}$. The initial temperature of the column was set at $35^{\circ} \mathrm{C}$, and temperature was increased to $275^{\circ} \mathrm{C}$ at a rate of $6^{\circ} \mathrm{C}$ per min. An acetic acid standard was set up and analyzed by the same technique by placing one drop of glacial acetic acid (Fisher Scientific Co., Pittsburgh, PA) in a 50-ml, sealed glass vial.

Effect of acetic acid on colony growth. Glacial acetic acid was added to CMA at $45^{\circ} \mathrm{C}$ to final concentrations of $0,5,10,25$, 50,100 , and $160 \mathrm{mg} / \mathrm{liter}$ of medium. The medium was poured into petri plates and allowed to solidify. A 5-mm disk from a 5day-old culture of $P$. nicotianae grown on V8 agar was placed in the middle of each plate, and the plates were incubated at $27^{\circ} \mathrm{C}$. After $96 \mathrm{~h}$, colony diameter of $P$. nicotianae was measured. The experiment was repeated once.

Data analysis. Data were subjected to analysis of variance using the General Linear Models procedure (SAS Institute, Cary, NC). Data from repeated experiments were combined when no significant differences existed between the experiments. Means were compared using least significant differences or paired $t$ test to distinguish differences among the treatments. The effect of increasing acetic acid on colony area was analyzed by using quadratic regression analysis.

\section{RESULTS}

Compost sources. The C:N ratio of CMW sources and batches ranged from 20 to 40 (Table 1). The bulk density was 0.34 $\mathrm{g} / \mathrm{cm}^{3}$ for each batch tested. All batches contained substantial $\mathrm{Ca}$ and micronutrient concentrations, with batch B2 particularly high in Fe. Both sources and batches of CMW were slightly alkaline, ranging from pH 7.50 to 7.91 .

Effect of CMW on seedling growth. No interaction between experiments was detected, so data were combined. Total plant fresh weight, shoot weight, and dried root weight decreased with increasing proportions of batch B4 CMW (Fig. 1). Electrical conductivity of the soils immediately after amendment was $0.11,2.01,3.45$, and $5.91 \mathrm{mS} / \mathrm{cm}$ for $0,10,20$, and $50 \%$ rates of CMW, respectively. After 8 weeks, the conductivity of the soil with increasing volumes of CMW was $0.14,0.28,0.35$, and $0.53 \mathrm{mS} / \mathrm{cm}$, respectively. Initial $\mathrm{pH}$ of CMW-soil mixtures was 5.67, 6.70, 6.69, and 7.37 for increasing volumes of CMW, respectively, and 5.55, 6.24, 6.55, and 7.13 after 8 weeks.

Infection of citrus seedlings by $\boldsymbol{P}$. nicotianae. There was no difference in the effect of CMW on infection of root systems in the seedling bioassay for the infested, nonamended treatment among experiments, so data were combined according to the age of CMW and citrus cultivar tested for analysis (Table 2). Amendment of soil with $10 \%$ of batch B4 lowered incidence of infection of $P$. nicotianae compared with the nonamended control ( $P \leq 0.01$; data not shown); but 
incidence was not further reduced by $20 \%$ CMW. Phytophthora-susceptible cultivars, Ridge Pineapple, sour orange, Cleopatra mandarin, and Volkamer lemon, had higher percent infection in nonamended soil infested with $P$. nicotianae than did tolerant cultivars, citrumelo hybrids F80-3 and F80-8. P. nicotianae was not detected in

When less than 6 months old, Batch R1a of Reuter CMW reduced infection by $P$. nicotianae for all cultivars tested except the tolerant citrumelo hybrid (F80-3) (Table 2). Batch R1b, which was stored at room temperature, did not suppress infection of Ridge Pineapple. Three-year-old batch R3 did not suppress infection of any cultivar. When batch B2 was less than 6 months old, infection of Ridge Pineapple was suppressed; but the same CMW aged 2.5 years did not suppress infection of this cultivar or the others. Batch B4 suppressed ange.

Populations of $P$. nicotianae recovered from CMW-amended soils after the completion of the seedling bioassay experiments ranged from 9 to 120 propagules per $\mathrm{cm}^{3}$ but were not significantly different from the nonamended, infested controls $(P$ $=0.49)$. Furthermore, no differences $(P=$ $0.99)$ among the citrus cultivars in recovery of $P$. nicotianae from soil were detected.

Effect of CMW on colony growth. Addition of fresh CMW from batches R1a, $\mathrm{R} 1 \mathrm{~b}, \mathrm{R} 3$, and $\mathrm{B} 2$ to different citrus soils the noninfested treatments. infection of Ridge Pineapple and sour or-

reduced colony development of $P$. nicotianae after the fungus was incubated in the amended soil for 6 days and then recovered on PARPH selective medium (Table 3 ). Batch B4 reduced colony area $(P \leq 0.001)$ to the same degree at 10 and $20 \%$ amendment rates compared with the nonamended treatment (data not shown).

Effect of sterile CMW extracts on colony growth. Cold water, $\mathrm{KOH}$, and $\mathrm{H}_{2} \mathrm{SO}_{4}$ extracts of batch B2 CMW added to CMA reduced colony area of $P$. nicotianae $(P \leq$ $0.05)$ compared with those extracts from nonamended soil (Table 4). Cold water and $\mathrm{KOH}$ extracts of batch R1a CMW did not reduce colony growth compared with soil extracts, although the $\mathrm{H}_{2} \mathrm{SO}_{4}$ extract from $\mathrm{CMW}$-amended soil increased colony area.

Isolation of microbial antagonists. Bright orange, mucoid fungal colonies were predominantly isolated from batch R1a PDA plates but were not recovered from other CMWs. When the bright orange colonies were grown in vitro in the presence of $P$. nicotianae, the orange fungus coiled around and penetrated $P$. nicotianae hyphae (Fig. 2). The isolate was identified as an Acremonium species. None of 100 bacteria or 49 other fungi isolated from CMWs showed any antagonistic behavior in vitro toward $P$. nicotianae.

Chromatography. A single peak with a retention time of $17.4 \mathrm{~min}$ was detected from an extract of fresh batch B2 of CMW. A smaller peak of the same retention time was also observed for extracts of fresh batches R1a and R3. The retention time of

Table 2. Incidence of root infection by Phytophthora nicotianae of seedlings of citrus cultivars in infested soil amended with composted municipal waste (CMW) of different sources and ages ${ }^{\mathrm{v}}$

\begin{tabular}{lccc}
\hline Cultivar $^{\mathbf{w}}$ & Treatment $^{\mathbf{x}}$ & $\begin{array}{c}\text { Age of compost } \\
\text { (years) }\end{array}$ & $\begin{array}{c}\text { Incidence of infection } \\
\text { (\%) }\end{array}$ \\
\hline Ridge Pineapple & Soil alone & $\ldots$ & $78 \%$ \\
Ridge Pineapple & $\mathrm{R}^{\mathrm{y}} \mathrm{y}^{\mathrm{y}}$ & 0.2 & $37 \% * * z$ \\
Ridge Pineapple & $\mathrm{R} 1 \mathrm{~b}$ & 0.2 & $55 \%$ \\
Ridge Pineapple & $\mathrm{R} 3$ & 3.0 & $90 \%$ \\
Ridge Pineapple & $\mathrm{B} 2$ & 0.2 & $20 \% * *$ \\
Ridge Pineapple & $\mathrm{B} 2$ & 2.5 & $90 \%$ \\
Ridge Pineapple & $\mathrm{B} 4$ & 0.3 & $30 \% * *$ \\
Citrumelo, F80-3 & Soil alone & $\ldots$ & $60 \%$ \\
Citrumelo, F80-3 & $\mathrm{R} 1$ & 0.2 & $43 \%$ \\
Citrumelo, F80-8 & Soil alone & $\ldots$ & $60 \%$ \\
Citrumelo, F80-8 & $\mathrm{R} 1$ & 0.2 & $22 \% *$ \\
Sour orange & Soil alone & $\ldots$ & $90 \%$ \\
Sour orange & $\mathrm{R} 3$ & 3.0 & $75 \%$ \\
Sour orange & $\mathrm{B} 4$ & 0.3 & $35 \% * *$ \\
Cleopatra mandarin & Soil alone & $\ldots$ & $94 \%$ \\
Cleopatra mandarin & $\mathrm{R} 1$ & 0.2 & $13 \% * *$ \\
Cleopatra mandarin & $\mathrm{B} 2$ & 2.5 & $100 \%$ \\
Volkamer lemon & Soil alone & $\ldots$. & $80 \%$ \\
Volkamer lemon & $\mathrm{R} 1$ & 0.2 & $0 \% * *$ \\
Volkamer lemon & $\mathrm{B} 2$ & 2.5 & $90 \%$ \\
\hline
\end{tabular}

v Candler fine sand infested with 10 chlamydospores of $P$. nicotianae per $\mathrm{cm}^{3}$ of soil.

${ }^{\text {w }}$ Five-week-old seedlings of Ridge Pineapple sweet orange, citrumelo hybrids F80-3 and F80-8, sour orange, Cleopatra mandarin, and Volkamer lemon.

${ }^{x}$ Pasteurized Candler fine sand nonamended or amended with 20\% (vol/vol) CMW batches from R1a, R1b, and R3 from Reuter Recycling (Pembroke Pines, FL) and batches B2 and B4 from Bedminster Bioconversion (Sevierville, TN).

${ }^{y}$ Batches R1a and R1b were from the same source; R1a was stored at $4{ }^{\circ} \mathrm{C}$ and $\mathrm{R} 1 \mathrm{~b}$ was stored at room temperature.

${ }^{\mathrm{z}}$ Significantly different from nonamended control at $P \leq 0.05$ (*) $^{*}$ or $P \leq 0.01$ (**) according to paired $t$ test. these peaks matched that of the acetic acid standard. Using a different chromatographic analysis for batch $\mathrm{B} 4$, a single peak was observed 2.8 min after injection, the same retention time as acetic acid by this methodology.

Effect of acetic acid on colony growth. Supplementation of CMA with increasing concentrations of acetic acid reduced colony diameter of $P$. nicotianae (Fig. 3). Quadratic regression analysis showed this

Table 3. Effect of amendment of two soil types with different sources and ages of composted municipal waste (CMW) on colony development of Phytophthora nicotianae

\begin{tabular}{lcc}
\hline Soil type $^{\mathbf{v}}$ & $\begin{array}{c}\text { CMW } \\
\text { treatment }^{\mathbf{w}}\end{array}$ & $\begin{array}{c}\text { Colony area } \\
\left(\mathbf{c m}^{\mathbf{2}}\right)^{\mathrm{x}}\end{array}$ \\
\hline Candler & Soil alone & $1.51 \mathrm{a}^{\mathrm{y}}$ \\
Candler & $\mathrm{B} 2$ & $0.73 \mathrm{c}$ \\
Candler & $\mathrm{R} 1 \mathrm{a}^{\mathrm{z}}$ & $0.71 \mathrm{c}$ \\
Candler & $\mathrm{R} 1 \mathrm{~b}$ & $1.11 \mathrm{~b}$ \\
Candler & R3 & $1.11 \mathrm{~b}$ \\
Wabasso & Soil alone & $1.37 \mathrm{a}$ \\
Wabasso & B2 & $0.77 \mathrm{bc}$ \\
Wabasso & R1a & $0.55 \mathrm{c}$ \\
Wabasso & R1b & $0.97 \mathrm{~b}$ \\
Wabasso & R3 & $1.05 \mathrm{~b}$ \\
\hline
\end{tabular}

${ }^{v}$ Two soil types collected near Davenport, FL (Candler fine sand) and Fort Pierce, FL (Wabasso fine sand).

w Treatments were $20 \%$ amendment of soils (vol/vol) with batch B2 from Bedminster Bioconversion CMW (Sevierville, TN) and batches R1 and R3 from Reuter Recycling CMW (Pembroke Pines, FL).

x Average colony area of $P$. nicotianae grown on PARPH selective medium $66 \mathrm{~h}$ after plating soil dilutions from infested, CMWamended or nonamended soils.

${ }^{y}$ Means followed by the same letter within a column and soil are not significantly different according to least significant differences $(P \leq$ $0.05)$.

${ }^{\mathrm{z}} \mathrm{R} 1 \mathrm{a}$ and $\mathrm{R} 1 \mathrm{~b}$ are from the same batch of Reuter CMW, except R1a was stored at $4^{\circ} \mathrm{C}$ while $\mathrm{R} 1 \mathrm{~b}$ was stored at room temperature.

Table 4. Effect of extracts of sterile soil and composted municipal waste (CMW) from different sources on colony development of Phytophthora nicotianae

\begin{tabular}{lccc}
\hline & \multicolumn{3}{c}{ Colony diameter $(\mathbf{m m})^{\mathbf{w}}$} \\
\cline { 2 - 4 } Treatment $^{\mathbf{x}}$ & Water $^{\mathbf{y}}$ & $\mathbf{K O H}$ & $\mathbf{H}_{\mathbf{2}} \mathbf{S O}_{\mathbf{4}}$ \\
\hline Soil & $70.9 \mathrm{a}^{\mathrm{z}}$ & $63.3 \mathrm{a}$ & $58.3 \mathrm{~b}$ \\
R1a & $71.3 \mathrm{a}$ & $62.0 \mathrm{a}$ & $71.3 \mathrm{a}$ \\
B2 & $51.9 \mathrm{~b}$ & $54.7 \mathrm{~b}$ & $50.7 \mathrm{c}$ \\
\hline
\end{tabular}

${ }^{\mathrm{w}}$ Average colony diameter of $P$. nicotianae grown on cornmeal agar after $88 \mathrm{~h}$.

$\times$ Soil dilutions were prepared from soil $(100 \mathrm{~g}$ per $100 \mathrm{ml}$ of extractant) or CMW batch R1a from Reuter Recycling (Pembroke Pines, FL) and batch B2 from Bedminster Bioconversion (Sevierville, TN) $(20 \mathrm{~g}$ per $100 \mathrm{ml}$ of extractant).

${ }^{y}$ Extractants were cold, double-distilled water (water), $0.4 \mathrm{~N} \mathrm{KOH} \mathrm{(KOH),} 2.0 \quad \mathrm{~N} \mathrm{H}_{2} \mathrm{SO}_{4}$ $\left(\mathrm{H}_{2} \mathrm{SO}_{4}\right)$.

${ }^{\mathrm{z}}$ Means followed by the same letter within a column are not significantly different according to least significant differences $(P \leq$ $0.05)$. 
growth reduction to be significant. Addition of acetic acid to CMA did not affect $\mathrm{pH}$ of the medium.

\section{DISCUSSION}

Incidence of root infection by $P$. nicotianae of susceptible citrus seedlings was reduced in a bioassay of typical Florida citrus soils amended with different sources and batches of CMW as long as they were relatively fresh ( $<6$ months from time of composting). However, as CMW aged, disease suppressiveness was lost, even when the $\mathrm{CMW}$ was stored at $4^{\circ} \mathrm{C}$. The temporary nature of the reduction in pathogen activity is consistent with field trials of the same batches of CMW $(37,38)$. Ap- plied as 10- to 15 -cm-thick mulches to newly planted or mature citrus trees, CMW did not reduce but sometimes increased populations of $P$. nicotianae. Nevertheless, CMW treatment of orchards appears promising because CMW increased growth and yield of trees despite increased pathogen activity.

Benefits of fresh CMW for disease suppression had to be balanced against the potential for phytotoxicity to citrus seedlings. Reduction in citrus seedling growth in the CMW-amended soil was probably due to high salinity and organic acids (e.g., acetic acid) in the growth media. An increase in conductivity as the CMW ratio increased in the medium supports this ex-
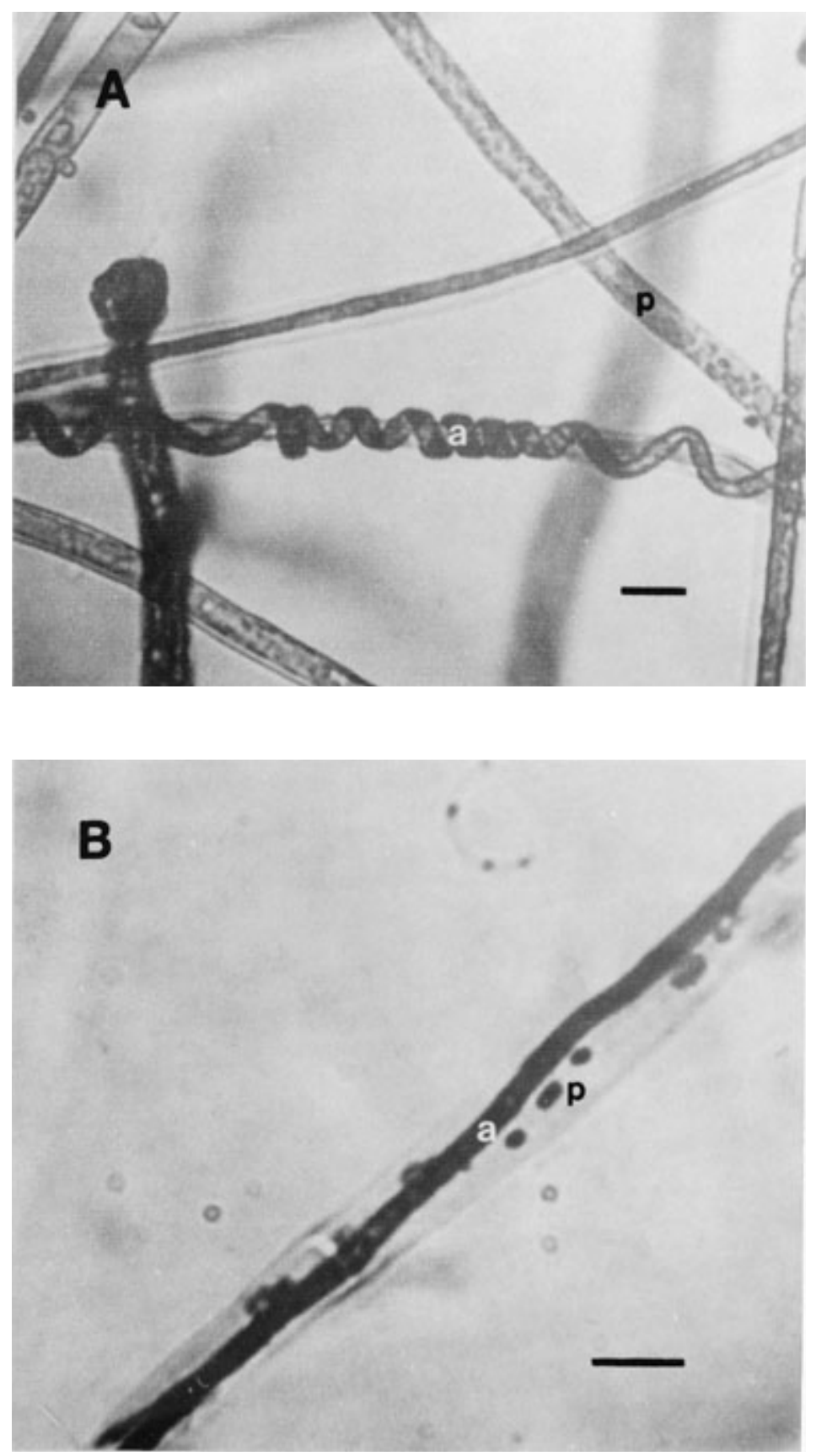

Fig. 2. Acremonium sp. parasitizing hyphae of Phytophthora nicotianae in vitro. (A) Hypha of Acremonium sp. coiling around $P$. nicotianae $(\times 1,100)$. (B) Hypha of Acremonium sp. within a hypha of $P$. nicotianae $(\times 1,800) . \mathrm{p}=$ P. nicotianae, $\mathrm{a}=$ Acremonium $\mathrm{sp} ., \mathrm{bar}=10 \mu \mathrm{m}$.

planation. Amendment of citrus soil with fresh CMW in excess of $20 \%$ by volume exceeded the acceptable recommended range of conductivity for agricultural soils of $3.5 \mathrm{mS} / \mathrm{cm} \mathrm{(36).} \mathrm{Citrus} \mathrm{roots} \mathrm{are} \mathrm{sensi-}$ tive to these salt concentrations, which cause physiological stresses and increase the susceptibility to Phytophthora root rot (5). Although the major ions $\left(\mathrm{Na}^{+}, \mathrm{K}^{+}\right.$, $\mathrm{Ca}^{2+}$, and $\mathrm{Mg}^{2+}$ ) that contribute to high salinity of refuse composts were present (23), the conductivity of the CMWamended sandy soil quickly dropped to noninhibitory levels, and pathogen infection was reduced by CMW. The phytotoxic effect of $20 \%$ CMW seen after 8 weeks probably would have been reversible had seedlings been grown over longer periods. Vavrina (35) observed in potting mixtures that different sources of CMW suppressed tomato seed germination and plant growth. Other studies have shown that, as time passes, the stand recovers from the initial growth suppression, and growth of subsequent crops is stimulated by CMW (28). In field studies of young trees $(37,38)$, temporary detrimental effects of high rates of CMW (150 MT/ha) were not observed.

Possible mechanisms for pathogen suppression by composts in planting mixes include inhibition of pathogen growth, pathogen survival, and reduction of infection (increased host resistance or competition for infection sites) of the host $(19,20)$. The capability for CMW to induce resistance of seedlings against Phytophthora root rot was not examined in this study. However, the effect of CMW and amended soil on the pathogen, $P$. nicotianae, was evaluated. Addition of as little as $10 \%$ (vol/vol) fresh CMW significantly reduced colony development in agar when the pathogen was incubated in amended soil or treated with extracts. Suppressiveness was expressed in different soil types representative of two major citrus-growing regions. Compost amendments, however, did not reduce the recovery of $P$. nicotianae from soil at the completion of bioassays. Thus,

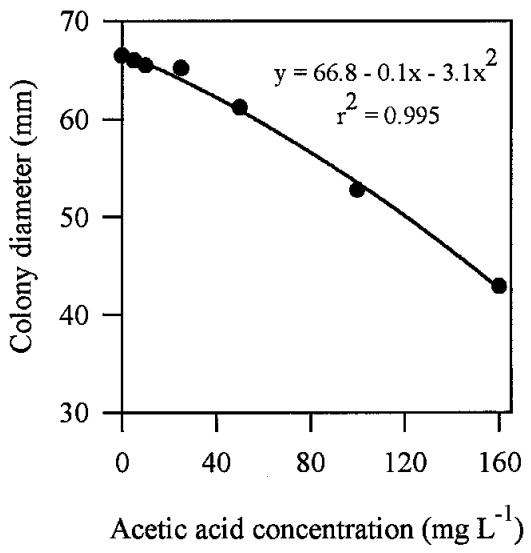

Fig. 3. Effect of acetic acid on colony growth of Phytophthora nicotianae on cornmeal agar plates after $96 \mathrm{~h}$. 
CMW was fungistatic to $P$. nicotianae, but not fungicidal, which may be important if seedlings are grown in CMW amendments and transplanted from the nursery to the field. Although the seedlings appear healthy, the pathogen may still be present and active in sufficient quantities to cause greater infection in the orchard.

A chemical agent was indicated by the suppression of $P$. nicotianae with sterile extracts of fresh batch B2 of CMW. Acetic acid was detected in fresh CMW that showed suppressive activity in bioassays but not in CMWs that lost activity after aging. Acetic acid is a product of anaerobic decomposition likely to be present in immature composts (8) and has been shown to suppress growth of $P$. cactorum (34).

Microbial antagonism was indicated for batch R1 of CMW, which showed suppressive behavior in the seedling bioassay but not in the growth of $P$. nicotianae in sterile extracts. An Acremonium sp. was isolated from the suppressive batch R1 CMW, but not from other batches and sources. When grown together, Acremonium sp. coiled around and penetrated $P$. nicotianae hyphae; however, colony suppression of $P$. nicotianae was not evident. Other Acremonium spp. have been found to be antagonistic toward plant pathogenic fungi. Malathrakis (26) found that A. alternatum severely damaged cucurbit powdery mildew, Sphaerotheca fuliginea.

In conclusion, the citrus seedling and chlamydospore incubation in soil provided quick bioassays for detecting disease and pathogen suppressive activity in different sources and batches of CMWs. Although CMWs proved suppressive to $P$. nicotianae under greenhouse conditions, the effect was lost after compost aged, and thus may prove ineffective for pathogen control in orchard applications. Nevertheless, field studies $(37,38)$ indicate that improved nutrient and water availability in Florida's sandy soils may provide long-term benefits due to increased root rot tolerance of citrus trees.

\section{LITERATURE CITED}

1. Agostini, J. P., Timmer, L. W., Castle, W. S., and Mitchell, D. J. 1991. Effect of citrus rootstocks on soil populations of Phytophthora parasitica. Plant Dis. 75:296-300.

2. Boehm, M. J., and Hoitink, H. A. J. 1992. Sustenance of microbial activity in potting mixes and its impact on severity of Pythium root rot of poinsettia. Phytopathology 82:259-264.

3. Bryan, H., Schaffer, B., and Crane, J. H. 1995. Solid waste compost for improved water conservation and production of vegetable crops (tomatoes/squash)--Homestead. Florida Water Conservation/Compost Utilization Program Final Report. Center for Biomass Programs, UF/IFAS, Gainesville, FL.

4. Carpenter, J. B., and Furr, J. R. 1962. Evaluation of tolerance to root rot caused by Phytophthora parasitica in seedlings of citrus and related genera. Phytopathology 52:1277-1285.

5. Castle, W. S., Tucker, D. P. H., Krezdorn, A. H., and Youtsey, C. O. 1993. Rootstocks for Florida citrus. University of Florida, Institute of Food and Agricultural Sciences SP42.
6. Chen, W., Hoitink, H. A. J., and Madden, L. V. 1988. Microbial activity and biomass in container media for predicting suppressiveness to damping-off caused by Pythium ultimum. Phytopathology 78:1447-1450.

7. Daft, G. C., Poole, H. A., and Hoitink, H. A. J. 1979. Composted hardwood bark: A substitute for steam sterilization and fungicide drenches for control of poinsettia crown and root rot. HortScience 14:185-187.

8. DeVleeschauwer, D., Verdonck, O., and Van Assche, P. 1981. Phytotoxicity of refuse compost. Biocycle 22:44-46.

9. E \& A Environmental Consultants. 1995. Development of suggested compost parameters and compost use guidelines. Final report. August 14, 1995. Florida Department of Agriculture and Consumer Services, Tallahasee, FL.

10. Ferriss, R. S. 1984. Effects of microwave oven treatment on microorganisms in soil. Phytopathology 74:121-126.

11. Fisher, J. 1993. Ciba-Geigy addresses Phytophthora resistance to Ridomil. Citrus Ind. 74:28-29.

12. Giusquiani, P. L., Patumi, M., and Businelli, M. 1989. Chemical composition of fresh and composted urban waste. Plant Soil 116:278-282.

13. Graham, J. H. 1990. Evaluation of tolerance of citrus rootstocks to Phytophthora root rot in chlamydospore-infested soil. Plant Dis. 74:743-746.

14. Graham, J. H. 1995. Screening for rootstock tolerance to Phytophthora: Progress and prospects. Citrus Ind. 76:18-21.

15. Gregoriou, C., and Rajkumar, D. 1984. Effects of irrigation and mulching on shoot and root growth of avocado (Persea americana Mill.) and mango (Mangifera indica L.). J. Hortic. Sci. 59:109-117.

16. Grimm, G. R., and Hutchison, D. J. 1977. Evaluation of Citrus spp., relatives, and hybrids for resistance to Phytophthora parasitica. Proc. Int. Soc. Citric. 3:863-865.

17. Hardy, G. E. St. J., and Sivasithamparam, K. 1991. Suppression of Phytophthora root rot by a composted Eucalyptus bark mix. Aust. J. Bot. 39:153-159.

18. Hoitink, H. A. J., Boehm, M. J., and Hadar, Y. 1993. Mechanism of suppression of soilborne plant pathogens in compost-amended substrates. Pages 601-621 in: Science and Engineering of Composting: Design, Environmental, Microbiological and Utilization Aspects. H. A. J. Hoitink and H. M. Keener, eds. Renaissance Publications, Worthington, $\mathrm{OH}$.

19. Hoitink, H. A. J., and Fahy, P. C. 1986. Basis for the control of soilborne plant pathogens with composts. Annu. Rev. Phytopathol. 24:93-114.

20. Hoitink, H. A. J., and Grebus, M. E. 1994. Status of biological control of plant diseases with composts. Compost Sci. Util. Spring:6-12.

21. Hoitink, H. A. J., Inbar, Y., and Boehm, M. J. 1991. Status of compost-amended potting mixes naturally suppressive to soilborne diseases of floricultural crops. Plant Dis. 75:869-873.

22. Hunt, P. G., Hortenstine, C. C., and Smart, G. C., Jr. 1973. Responses of plant parasitic and saprophytic nematode populations to composted municipal refuse. J. Environ. Qual. 2:264-266.

23. Inbar, Y., Chen, Y., and Hoitink, H. A. J. 1993. Properties for establishing standards for utilization of composts in container media. Pages 668-694 in: Science and Engineering of Composting: Design, Environmental, Microbiological and Utilization Aspects. H. A. J. Hoitink and H. M. Keener, eds. Renaissance Publications, Worthington, $\mathrm{OH}$

24. Inbar, Y., Hadar, Y., and Chen, Y. 1993. Recycling of cattle manure: The composting process and characterization of maturity. J. Environ. Qual. 22:857-863.
25. Lumsden, R. D., Lews, J. A., and Millner, P. D. 1983. Effect of composted sewage sludge on several soilborne pathogens and diseases. Phytopathology 73:1543-1548.

26. Malathrakis, N. E. 1985. The fungus Acremonium alternatum Linc:Fr., a hyperparasite of the cucurbits powdery mildew pathogen Sphaerotheca fuliginea. J. Plant Dis. Prot. 92:509-515.

27. Mitchell, D. J., and Kannwischer-Mitchell, M. E. 1992. Phytophthora. Pages 31-38 in: Methods for Research on Soilborne Phytopathogenic Fungi. L. L. Singleton, J. D. Mihail, and C. M. Rush, eds. American Phytopathological Society, St. Paul, MN.

28. Obreza, T. A., and Reeder, R. K. 1994. Municipal solid waste compost use in tomato/ watermelon successional cropping. Soil Crop Sci. Soc. Fla. Proc. 53:13-19.

29. Ownley, B. H., and Benson, D. M. 1992. Evaluation of Penicillium janthinellum as a biological control of Phytophthora root rot of azalea. J. Am. Soc. Hortic. Sci. 117:407-410.

30. Peech, M. 1965. Hydrogen-ion activity. Pages 914-926 in: Methods of Soil Analysis. Part 2, Chemical and Microbiological Properties. C. A. Black, D. D. Evens, J. L. White, L. E. Ensiminger, and F. G. Clarke, eds. American Society of Agronomy, Madison, WI.

31. Schueler, C., Biala, J., and Vogtmann, H. 1989. Antiphytopathogenic properties of biogenic waste compost. Agric. Ecosyst. Environ. 27:477-482.

32. Steffen, A., and Pawliszyn, J. 1996. Analysis of flavor volatiles using headspace solidphase microextraction. J. Agric. Food Chem. 44:2187-2193.

33. Timmer, L. W., Graham, J. H., and Zitko, S. E. 1998. Metalaxyl-resistant isolates of Phytophthora nicotianae: Occurrence, sensitivity, and competitive parasitic ability on citrus. Plant Dis. 82:254-261.

34. Utkhede, R. S., and Gaunce, A. P. 1983. Inhibition of Phytophthora cactorum by a bacterial antagonist. Can. J. Bot. 61:3343-3348.

35. Vavrina, C. S. 1994. Municipal solid waste materials as soilless media for tomato transplant production. Proc. Fla. State Hortic. Soc. 107:118-120.

36. Warnke, D. 1988. Recommended test procedure for greenhouse growth media. Pages 34 37 in: Recommended Chemical Soil Test Procedures for the North Central Region. Publ. 221 (Revised) Bull. 499 (Revised), North Dakota State University, Fargo.

37. Widmer, T. L., Graham, J. H., and Mitchell, D. J. 1996. The effect of composted municipal waste as a soil amendment on the growth of young citrus trees and Phytophthora nicotianae. Soil Crop Sci. Soc. Fla. Proc. 55:32-36.

38. Widmer, T. L., Graham, J. H., and Mitchell, D. J. Potential use of composted municipal waste for management of Phytophthora root rot of bearing citrus. Proc. Fla. State Hortic. Soc. In press.

39. Wolf, D. C., and Skipper, H. D. 1994. Soil sterilization. Pages 41-51 in: Methods of Soil Analysis. Part 2, Microbiological and Biochemical Properties. R. W. Weaver et al., eds. Soil Science Society of America, Madison, WI.

40. Zhang, Z., and Pawliszyn, J. 1993. Head space solid-phase microextraction. Anal. Chem. 65:1843-1852.

41. Zitko, S. E., Timmer, L. W., and Castle, W. S. 1987. Survey of Florida citrus nurseries for Phytophthora spp. Proc. Fla. State Hortic. Soc. 100:82-85.

42. Zucconi, F., Forte, M., Monaco, A., and de Bertoldi, M. 1981. Biological evaluation of compost maturity. Biocycle 22:27-29.

43. Zucconi, F., Pera, A., Forte, M., and de Bertoldi, M. 1981. Evaluating toxicity of immature compost. Biocycle 22:54-57. 